\title{
GSM Operatörü Markalarının Sosyal Sorumluluk Çalışmaları: Kurumsal Web Sayfaları Üzerine Bir Analiz
}

\author{
Özer Silsüpür (Öğr. Gör. Dr.) \\ Trabzon Üniversitesi Illetişim Fakültesi \\ ozer.silsupur@gmail.com \\ Bașvuru Tarihi: 08.03.2021 \\ Yayına Kabul Tarihi: 10.05.2021 \\ Yayınlanma Tarihi: 30.07.2021 \\ https://doi.org/10.17680/erciyesiletisim. 892812 \\ Öz
}

Markalar sosyal sorumluluk çalışmalarıyla toplumsal sorunlara dikkat çekmek, bu sorunlara çözümler üretmek, insanların hayatlarına dokunmak ve böylece toplumla yakınlaşmaktadırlar. Markalar, gönüllülük esasıyla gerçekleştirdikleri sosyal sorumluluk çalışmalarını, önemli bir iletişim aracı olan kurumsal web sitelerinde paylaşmakta ve hedef kitleleri bilgilendirmektedirler. Markalar web sayfaları sayesinde, hedef kitlelerle hem hızlı hem de aracısız ve doğrudan iletişim kurabilmekte, bunun sonucunda oluşacak güvenle de marka imajlarına olumlu katkı sağlamaktadırlar. Bu bağlamda çalıșmada, Türkiye'de ürün ve/veya hizmetleriyle faaliyet gösteren Turkcell, Vodafone ve Türk Telekom GSM operatörü markalarının sosyal sorumluluk mesajlarını kurumsal web sayfaları üzerinden değerlendirmek amaçlanmış ve bu doğrultuda markaların kurumsal web sayfaları içerik analizi yöntemiyle 19.02.2021-05.03.2021 tarihleri arasında incelenmiştir. Araştırmanın sonucunda, üç markanın da web sayfalarında sosyal sorumluluk mesajlarına yer verdiği görülmüştür. Turkcell sosyal sorumluluk mesajlarını "sponsorluk" linki içinde paylaşırken, Vodafone ve Türk Telekom'un sosyal sorumluluk linkleri olduğu tespit edilmiştir. Markaların en çok çevre, eğitim ve toplum alanlarında sosyal sorumluluk mesajı paylaştığı; turizm, kültür-sanat, spor alanlarında ise hiçbir sosyal sorumluluk faaliyetlerinde bulunmadıkları saptanmıştır. GSM operatörleri mesajlarını en çok metin aracılığıyla, daha sonra görsel ve yazılı materyal ve görsel ve işitsel materyal kullanarak paylaștıkları belirlenmiștir. GSM operatörleri içinde marka değeri açısından ikinci olan Turkcell'in en fazla sosyal sorumluluk çalışması gerçekleştirdiği tespit edilmiştir.

Anahtar Kelimeler: Sosyal Sorumluluk, Kurumsal Web Sayfaları, GSM Operatörü Markaları, İçerik Analizi. 


\title{
Social Responsibility Activities of GSM Operator Brands: An Analysis on Corporate Web Pages
}

\author{
Özer Silsüpür (Lect. Ph.D.) \\ Trabzon University Faculty of Communication \\ ozer.silsupur@gmail.com \\ Date Received: 08.03.2021 \\ Date Accepted: 10.05 .2021 \\ Date Published: 30.07.2021 \\ https://doi.org/10.17680/erciyesiletisim.892812
}

\begin{abstract}
Brands' social responsibility activities draw attention to social problems, create solutions to problems, touches the lives of people and get closer to society. Brands, share their voluntary basis social responsibility activities on corporate web pages to inform target audience. Brands can communicate with their target audiences quickly and without intermediary through their web pages, creating a reliance and contribute positively to their brand image. In this research, brands operating a product and/or a service, Turkcell, Vodafone and Turk Telekom GSM operator brands' social responsibility messages assessed through corporate web pages. In this respect, corporate web pages were examined with content analysis method between 19.02.2021-05.03.2021. As a result, it was seen that three brands include social responsibility messsages on their web pages. While Turkcell shares responsibility messages within a "sponsorship" link, Vodafone and Turk Telekom have social responsibility links. Brands mostly share social responbility messages about environment, education and society, meanwhile share nothing about tourism, culture-arts and sports. GSM operators shared their messages mostly through text, then with visual and written materials and visual audio materials. Turkcell, which is the second among GSM operators in terms of brand value, has carried out the most social responsibility activities.
\end{abstract}

Keywords: Social Responsibility, Corporate Web Pages, GSM Operator Brands, Content Analysis. 


\section{Giriş}

Sorumluluk, bireylere verilen görevleri ve ödevleri yerine getirme mecburiyeti (Certo, 1997, s. 251) ve bireylerin eylemlerinin sonuçlarını ya da yetkisine giren herhangi bir olayın sonuçlarını kabul etmesidir (Türk Dil Kurumu [TDK], 2021). Markalar/ İşletmeler günümüz koşullarında gerek ekonomik gerekse de sosyal yapı (varlık) olarak görüldügüüden, kâr etmeleri dışında topluma yararlı faaliyetlerde bulunmaları gerekmektedir (Ölçer, 2015, s. 26-27). Küresel boyutta yaşanan rekabet ortamında ve teknolojinin hükmettiği sistemde üstünlük kurmak ve söz sahibi olmak için markalardan toplumsal alanda fayda sağlamaları (Toker \& Tat, 2013) ve toplumun ihtiyaçlarına karşılık vermeleri beklenmektedir.

Toplumda çeşitli görevler üstlenerek faaliyet gösteren markalar; toplumsal, ekonomik, teknolojik gelişmelerden ve değişimlerden etkilenmektedir. Esas olarak kâr etme düşüncesiyle hareket etmesi beklenen markaların, topluma karşı bazı sorumlulukları olduğu fikri bu değişimin bir sonucudur. Bireylerin eylem ve faaliyetlerinin sonuçlarını kabul etmesi olan sorumluluğun, zamanla topluma ürün ve/veya hizmetler sağlayarak kazanan markaların, topluma karşı sorumlulukları, görevleri olduğu düşüncesini doğurmuş ve bu bilinç toplumda gelişmeye başlamıștır. Bu sebeple markalar ürün ve/ veya hizmetleriyle hem yerel hem de küresel ölçekte insana değer vererek topluma fayda sağlamalı, yaşanabilir bir çevre bırakmalı, şeffaf ve hesap verebilir olmalı (Silsüpür, 2020, s. 19-20), iş ahlakına önem vermeli, çalışanların haklarını teslim etmeli ve uluslararası standartlara göre üretim yaparak ekonomik kalkınmaya destek olmalıdırlar.

Markaların/İșletmelerin gerek doğal ve ekonomik kaynakları kontrolsüzce tüketmesi, üretim kapasitelerine ve faaliyetlerine bağlı olarak çevreyi/doğayı kirletmeleri, küresel ısınmaya sebep olmaları gibi ekonomik faaliyetleri sonucu gelişen olumsuz etkiler gerekse de yeryüzündeki kaynakların nüfus artışına oranla azalması gibi sebepler sosyal sorumluluk düşüncesinin oluşmasına ortam hazırlamıștır (Top, 2015, s. 100). Ayrıca küreselleşme ve liberalleşme politikaları, iklim değişiklikleri, sivil toplum kuruluşlarının, rakip markaların, çalışanların ve diğer paydaşların baskıları da markaları sosyal sorumluluk düşüncesine yönlendirmiştir (Warhurst \& Mitchell, 2000). Markaların yönetimlerinde zamanla gelişen insan odaklı bakış açısı, insanın merkeze koyulması ve insanların sorunları üzerine çözümler üretilmesi fikri, sosyal sorumluluğun sivil toplum kuruluşları sayesinde gelişmesine imkân sağlamıştır (İlic, 2015, s. 69). Dolayısıyla markalar sosyal sorumluluk faaliyetleriyle iç ve dış hedef kitlelere karşı sorumlu davranışlar göstererek faaliyet gösterilen iş piyasasında büyümeyi sağlamakta (Rasoulzadeh, Hosseinipour, Yusof, Soltani, \& Hashemi, 2013), sosyal sorumluluk anlayışını eylemlerinde göstererek saygınlık ve değer kazanmaktadır (Isiri \& Crowther, 2015). Ayrıca faaliyetlerinde insanı odağına koyan ve insan temelli çalışmalar yapan markaların imajının da bundan olumlu etkilenmesi mümkündür.

Sosyal sorumluluk uygulamaları; sürdürülebilir kalkınmanın gelişmesinde, toplumsal bilincin oluşmasında, toplumda yapılması gereken eksik kalan çalışmaların tamamlanmasında (Demirtaş, 2015, s. 4), yerleşmiş bazı davranışların değiştirilmesinde, yaşam şartlarının iyileştirilmesinde, istihdam sağlanmasında, kalkınmanın desteklemesinde, çevrenin/doğanın korunmasında, kültürel değerlere sahip olunmasında, eğitime destek verilmesinde, göçün durdurulmasında, tarımın teşvik edilmesinde (Gürel, 2007, s. 30), sorunlara çözümler üretilmesinde, markaların olumlu şekilde algılanmasında, müşterilerle (tüketicilerle) marka arasında bağ kurulup sadakatin sağlamasında, marka bilinirliğinin (farkındalığının) artmasında ve markaya 
güven sağlanmasında önemli rol oynamaktadır (Silsüpür, 2020, s. 23-25). Bu bağlamda çalışma, Türkiye'de ürün ve/veya hizmetleriyle faaliyet gösteren Turkcell, Vodafone ve Türk Telekom GSM operatör markalarının sosyal sorumluluk mesajlarını kurumsal web sayfaları üzerinden değerlendirmektir. Bu amaçla Turkcell, Vodafone ve Türk Telekom markalarının sosyal sorumluluğa yönelik çalışmaları web sayfaları üzerinden içerik analizi yöntemiyle 19.02.2021-05.03.2021 tarihleri arasında incelenmiştir.

\section{Sosyal Sorumluluk}

Howard Bowen'ın 1953 yllında yayımlanan “Social Responsibilities of Businessman (İşs Adamının Sosyal Sorumlulukları)" kitabında ilk kez kullanılan sosyal sorumluluk (Carroll, 1999, s. 269), iş adamlarının toplumsal değerleri ve hedefleri düşünerek, toplumun istenilen aşamaya gelmesi için yapması gereken zorunlulukları ifade etmiştir (Bowen, 1953, s. 6). Sosyal sorumluluk kavramının ilk duyulduğu bu yıllarda, iş adamlarının sahip olduğu nüfuz ve gücün etkisiyle markaların/işletmelerin toplumsal sorumluluğundan ziyade iş adamlarının sorumlulukları ve iş adamlarının toplumsal faaliyetleri üzerinde durulmuştur. Bu sebeple sorumluluğun önceleri markalar/işletmeler yerine markaların kurucusu veya sahibi olan iş adamının sorumlulukları olduğu düşüncesi hâkim olmuş, zamanla yaşanan sosyal değişimler neticesinde ise markaların/işletmelerin sorumluluğuna dönüşmüştür. Dolayısıyla zaman içerisinde yaşanan bu değişimlerin sosyal sorumluluk kavramına nasıl yansıdığını anlamak için geçmişten günümüze çeşitli yazarlardan tanımlamalar yapılması isabetli olacaktır.

- Sosyal sorumluluk; markaların gerek kendi gerekse de toplumun menfaatlerini düşünerek, toplumsal gelişmenin sağlanması için yaptığı çalışmalardır (Davis, 1960, s. 70; Certo, 1997, s. 51).

- Sosyal sorumluluk; markaların istediği amaçlara ulaşmasında hizmet sağladığı topluma karşı yardımcl, destekleyici faaliyetlerdir (Steiner, 1979, s. 37).

- Sosyal sorumluluk; markaların sınırlı kaynakları uygun şekilde kullanarak toplumun beklenti ve taleplerine göre üretim yapması ve de ekonomik faaliyetleri bütün paydaşlarını düşünerek, onlara zarar vermeden gerçekleștirmesidir (Çelik, 2007, s. 62).

- Sosyal sorumluluk; markaların kâr sağlamak dışında ekonomik, sosyal, kültürel ve çevresel faaliyetleri gönüllü destekleyerek, markanın uzun vadede hizmet etmesini sağlamaya yönelik çalışmalardır (Ceritoğlu, 2011, s. 23).

- Sosyal sorumluluk; markaların yerel ve küresel boyutta faaliyet gösterdikleri toplumlara gönüllük esaslı ekonomik destek vermesidir (Seitel, 2016, s. 275).

- Sosyal sorumluluk; markaların toplumun sorunlarının fark edilmesini sağlamak, sorunların çözümüne yardımcı olmak ve toplumsal refahın artmasını sağlamak için yaptı̆̆ı gönüllü çalışmalardır (Carroll, 2016, s. 4).

Sosyal sorumluluk; markaların ekonomik kazanç sağlamalarının ve yasalara uymalarının dışında topluma fayda sağlamayı gerektirmektedir (Keith, 1973, s. 312). Avrupa Komisyonu; markaların/işletmelerin kanunlara uymak, toplumsal beraberliği sağlamak, iş ahlakı, insan hakları, doğa ve eğitim için çalışmalar yapma sorumlulukları olduğunu ifade etmektedir (European Commission, 2021). Dolayısıyla toplumsal kalkınmaya ve eğitime destek olmak, üretim faaliyetlerinde çevre ve doğaya önem göstermek, etik kuralları gözeterek iç ve dış paydaşlarla iş yapmak gibi davranışlar ve sorumluluklar markalara birtakım kazanımlar sağlamaktadır. Bu kazanımları Hodgetts ve Kurakto (1991) şöyle açıklamaktadır: Müşterilerin (tüketicilerin) ve çalışanların markaya olan 
bağlılığını (sadakatini) artırmak, müşterilerin markayı daha iyi tanımasını sağlamak, marka ve paydaş ilişkisi kurmak, geliștirmek, markaya itibar sağlamak ve markalar arasındaki rekabette üstünlük kurmak.

Sosyal sorumluluk odaklı hareket eden markaların sadece ürün ve/veya hizmetlerinin satışları artmamakta, aynı zamanda markaya güven ve saygı artmakta, olumlu marka imajı gelişmekte, markanın değerinde artış olmakta (Silsüpür, 2020, s. 46), markanın bilinirliği ve tercih edilirliği artmakta, rekabet ortamında avantaj kazanmakta ve sosyal adaletin sağlanmasına da destek olmaktadır.

\section{Sosyal Sorumluluk Alanları}

Markaların hem faaliyette bulunduğu ülkeye, topluma hem de uluslararası alanda sosyal ve ekonomik sorumlulukları vardır. Markalar topluma fayda sağlayarak ve hedef kitlelerin beklentilerini dikkate alarak bazı sorumlulukları yerine getirmelidirler (Aktan \& Vural, 2007). Bu sebeple markalar; topluma, çevreye ve doğaya, müşterilere (tüketicilere), çalışanlara, hissedar ve yatırımcılara, tedarikçilere, devlete, demokrasi ve insan hakları, eğitim, kültür, sağlık ve refah konularına karşı sorumluluklara sahiplerdir (Silsüpür, 2020, s. 65-66).

\subsection{Topluma Karşı Sorumluluk}

Ürün ve/veya hizmet sağladığı toplumdan kazanan markaların topluma olan teşekkürlerini göstermek için ya da sosyal, yasal sebeplerle görevlerini yerine getirmek amacıyla faaliyetler gerçekleștirmektedirler (Aydınalp, 2013, s. 18). Bu bağlamda markaların topluma ve toplumsal sorunlara karşı sorumluluklarından bazıları şunlardır (Torlak, 2013, s. 42): Yoksulluğa, açlığa, işsizliğe, şiddete ve madde bağımlılığına karşı mücadele, engellilere iş imkânı sağlama, eğitime destek verme ve yaşlılara bakıma destek olma.

Toplumun beklentilerini göz önünde bulundurarak toplumla beraber çalışmalar yapan markaların (Higgins, Stubbs, \& Milne, 2018) gösterdikleri sorumluluk sayesinde hem bilinirlikleri artacak hem de hedef kitleler nezdinde olumlu algılanarak marka imajlarına katkı sağlanacaktır.

\section{2. Çevreye ve Doğaya Karşı Sorumluluk}

İnsanların ve canlıların üzerinde hızlı bir șekilde veya belli bir sürede, doğrudan ya da dolaylı etkide bulunabilen kimyasal, biyolojik, fiziksel ve toplumsal etkenlerin birleşimi olan çevre (Keleş \& Hamamcı, 2002) açısından sürdürülebilirlik önemlidir. Bu sebeple yeryüzündeki kaynakların yeniden kullanılmasına dikkat edilmeli, çevreye zarar vermeyen ve doğada dönüșebilen maddeler kullanılmalıdır (Peattie, 1999, s. 133).

Kaynakların kirlenmesi, canlı türlerinin yok olması, bitkilerin ve hayvanların yaşam alanlarının zarar görmesi gibi çevre sorunları insan eylemleri sonucunda meydana gelmektedir (Birden, 2016, s. 12). Dolayısıyla markaların üretimlerini yaparken çevreyi kirletmemek, canlılara ve doğaya zarar vermemek, doğal kaynakları ve hammaddeleri bilinçli kullanmak, zehirli atıkları doğaya bırakmamak gibi çevreye ve doğaya karşı sorumlulukları vardır (Metin, 2006, s. 164).

\subsection{Müşterilere (Tüketicilere) Karşı Sorumluluk}

Markalar müşteri ihtiyaçlarına yönelik ürün veya hizmetlerinde güvenilir ve kaliteli olmalarının yanında (Aktan \& Vural, 2007), insan sağlı̆̆ına zarar vermemeli, müşterilerin beklentilerine uygun ürünler üretmeli, ürün ya da hizmetlerin reklamlarında yanıltıcı 
olmamalıdır (Nalbant, 2005, s. 200). Markaların müşterilerine karşı diğer sorumlulukları ise şunlardır (Hay \& Gray, 1981): Müşterileri ürün ve hizmetler hakkında bilgilendirmek, müşterilerin ürün ve hizmetlerle ilgili şikâyetlerini almak ve değerlendirmek, ürün ve hizmetleri uygun ücretle, doğru zamanda ve müşteriyi kandırmadan satmak.

\section{4. Çalışanlara Karşı Sorumluluk}

Markalar; çalışanlarına uygun gelir, sağlıklı ve huzurlu bir çalışma ortamı, onların kabiliyetlerine göre ilerleme imkânı sunarak, sosyal haklarını vererek, sendika kurmalarına ve grev haklarına engel olmayarak sorumluluklarını yerine getirmelidirler (Tosun, 1979, s. 7). Ayrıca markalar; çalışanlara hak edilen ücreti vererek, ücretlerin ekonomik süreçler göz ününde bulundurularak yılda en az bir kere artış yapılarak, çalışanların motivasyonlarını artıracak çalışma düzeni sağlayarak, her bir çalışana eşit davranış sergileyerek ve çalışanlar arasında çıkar çatışmasına engel olarak, çalışanları görevleriyle ilgili bilgilendirerek, çalışanları pozisyonlarıyla alakalı olarak karar alma ve vermelerini cesaretlendirerek de çalışanlarına karşı sorumluluk görevlerini yapabilirler (Silsüpür, 2020, s. 77-78).

\subsection{Tedarikçilere Karşı Sorumluluk}

Markalar, ürün ve hizmet alımı yapacakları tedarikçilerine karşı adil davranmalı, herkese eşit ücret tekliflerinde bulunmalı, tedarikçilerden gelen fiyat önerilerini adaletli değerlendirmeli, tedarikçiler arasında ayrımcılık yapmadan onları objektif kriterlere göre değerlendirmeli ve her iki taraf arasında adil bir anlaşma yapılmalıdır (Torlak, 2013, s. 43). Dolayısıyla markalar rekabetin yoğun yaşandığı piyasa şartlarında tedarikçilerden sağlam ve dayanıklı, kalite-fayda dengesinin özen gösterildiği ve insan sağlığına zarar vermeyen malzemeler tercih etmelidir (Silsüpür, 2020, s. 79).

\subsection{Hissedarlar ve Yatırımcılara Karşı Sorumluluk}

Markalar için yatırımcı güvenini kazanarak maliyetleri en aza indirmek, yatırımcı çeşitliliği elde etmek ve bu sayede ekonomik kazanç sağlamak önemlidir (Abdul Hamid, Salleh, \& Yusof, 2002). Bu nedenle markaların yatırımcılara karşı sorumlulukları arasında; yatırımcı çıkarlarını güvence altına almak, maksimum kâr, sürekli istihdam ve iş imkânlarında çeşitlilik sağlamak, kaliteli mal ve hizmet sunmak yer almaktadır (Çelik, 2007, s. 69).

\subsection{Devlete Karşı Sorumluluk}

Markaların yatırımları için önemli bir güven unsuru olan devlete karşı bazı sorumlulukları vardır. Bu sorumluluklar şöyledir (Diken \& Çelebi, 2015): Vergi vermek, yasalara uymak, üretim yaparken çevreye zarar vermemek ve istihdama destek olmak.

\section{Web Sayfalarının Sosyal Sorumluluk Açısından Kullanımı}

İnternet; ses, fotoğraf, video, grafik, metin gibi birçok iletişim şekillerinin bir arada kullanıldığı, küresel ölçekte erişim imkânı sunan, zaman ve mekânla sınırlı olmayan bir iletișim aracıdır (Timisi, 2003, s. 124). İnternetin hızlı, basit, ekonomik, güncellenebilir, ölçülebilir olması, kişilerarası iletişime olanak sağlaması ve kurumsal imaja katkı sağlaması halkla ilişkiler faaliyetlerinde önemini ortaya koymaktadır (Aksoy, 2006, s. 60). Dolayısıyla internetin sağladığı bu ve daha birçok olanaklarla çok sayıda hedef kitleye erișebilen (Peltekoğlu, 2004, s. 276) markalar gerek mevcut gerekse de hedefledikleri gruplarla sürdürecekleri iletişim politikalarında diyaloga açık olmalı ve geri dönüşlere dikkat etmelidir. 
Markalar internetin sağladığı interaktif medya sayesinde elektronik posta, web sayfası ve yeni bilgi teknolojileriyle yeni kurumsal iletişim alanına kavuşmuşlardır. Markalar geleneksel medya araçlarıyla pasif hedef gruplara ulaşmak yerine, yeni iletişim teknolojileriyle aktif hedef kitlelere ulaşmak ve bilgi alışverişi sağlamanın imkânına sahip olmuşlardır (Esrock \& Leichty, 1998). Bu sebeple web sayfaları, marka hakkında bilgi sunması ve yapılan çalışmaların tanıtımın yapılmasını sağlaması bakımından halkla ilişkiler uzmanlarının etkili biçimde kullandığı araçlardan biri olmuştur (Çöklü, 2004, s. 17).

Web sayfaları hem kamu hem de özel sektör kuruluşlarının hizmetler hakkında bireylerin düşüncelerini, önerilerini, taleplerini ve görüşlerini öğrenmek amacıyla kullandıkları (Bobbitt, 1995, s. 29), dijital teknolojinin sağladığı 7 gün 24 saat erişme, zaman ve mekân bağımsızlığı sayesinde önemli bilgi kaynağı olmasının yanında, markaların hedef kitlelere tanıtıldığı ve hedef kitlelerin de geri bildirimleriyle markaları tanıdığı bir iletişim ortamıdır (Yalın \& Silsüpür, 2017). Dolayısıyla web sayfaları; güncellenebilir özelliğiyle yeni bilgilerin hızlıca paylaşılmasına, bilginin kurum içinden paylaşımının sağlanmasına ve bilgi kirliliğinin önlemesine, markaların ürün ve/veya hizmetleriyle ilgili bilgi verilmesine ve gerçekleştirdikleri çalışmalar hakkında kamuoyunun bilgilendirilmesinin sağlanmasına, sponsorluk, sosyal sorumluluk gibi uygulamaların hedef kitlelerle paylaşılmasına imkân vermesi ve marka imajını güçlendirilmesi ve pekiştirilmesi bakımından günümüz iletişim çağında önemli bir başvuru kaynağı olmuştur.

Web sayfalarında paylaşılan bilgilerin güncel ve faydalı olmasına, kullanıcıların tekrar ziyaret etmesini sağlayacak ara yüz tasarımının ilgi çekici ve kolay olmasına, verilen linklerin güncel olmasına ve iki yönlü iletişim açısından geri bildirimlere dönüş sağlanmasına önem verilmelidir (Kent \& Taylor, 1998). Bu bakımdan web sayfalarının; markaların kuruluşu hakkında bilgiyi paylaşmak, markaların yeni ürün veya hizmetlerini duyurmak, reklam ve tanıtımını yapmak ve çevrimiçi satış gerçekleştirmek, müşteri hizmetlerini elektronik ortamda sağlamak, kurum imajının sergilenmesi gibi kullanım amaçları söz konusudur (Çakır, 2011, s. 159).

\section{Yöntem}

Bu bölümde araştırmanın amacı, önemi, yöntemi, sınırlılığı ve soruları yer almaktadır.

Bir araştırma tekniği olan içerik analizi; yazılı belgelerde, reklam, fotoğraf, film gibi iletişim araçlarında yer alan bilgiyi, sembolleri araştırmaya, temaları kodlamaya ve sinıflandırmaya yaramaktadır (Hsieh \& Shannon, 2005; Neuman, 2014, s. 49). Web 2.0 teknolojileri içerik oluşturmaya olanak sağladığından, bu içeriklerin incelenmesinde web sayfalardaki paylaşımların veya mesajların araştırılmasında içerik analizi yöntemi kullanılmaktadır (Kim \& Kuljis, 2010). Bu çalışmada GSM operatörü markalarının sosyal sorumluluk mesajlarının kurumsal web sayfalarında nasıl duyurulduğu ele alınmış ve bunu incelemek için içerik analizi tekniğinden yararlanılmıştır.

Çalışmada, sosyal sorumlulukla ilgili linklerin web sayfalarındaki konumu ve sosyal sorumlulukla ilgili mesajların web sayfalarında iletilme biçimlerine ilişkin sorgulamada Esrock ve Leichty'in (1998) sınıflandırmasından yararlanılmıştır.

Kodlama cetveli oluşturulurken yerli ve yabancı araștırmacıların (Aktan \& Börü, 2007; Alnıaçık, Develi, Giray, \& Alnıaçık, 2011; Anderson, 1982; Carroll, 1991; Çelik, 2007) (Güllülü, Ünal, Gödekmerdan, \& Deniz, 2010; Hatherly, Mitchell, Mitchell, \& Lee, 2017; McWilliams \& Siegel, 2000) sosyal sorumluluk uygulama alanlarına yönelik 
sınıflandırmaları da incelenmiş ve bu alanların topluma karşı sorumluluk, doğaya ve çevreye karşı sorumluluk, tüketicilere (müşterilere) karşı sorumluluk, çalışanlara karşı sorumluluk, tedarikçilere karşı sorumluluk, hissedar ve yatırımcılara karşı sorumluluk ve devlete karşı sorumluluk olduğu görülmüştür. Zaman içerisinde yaşanan sosyal değişimler neticesinde sorumluluk alanlarında çeşitlilik meydana gelmiş ve "eğitim ve kültür", "demokrasi ve insan hakları", "sağlı ve refah" gibi sosyal sorumluluk kategorileri de oluşmuştur (Silsüpür, 2020, s. 65). Ayrıca Türkiye Halkla İlişkiler Derneği'nin 1991 yılından beri her yıl başarılı halkla ilişkiler çalışmalarını ödüllendirmek ve teşvik etmek amacıyla "Altın Pusula Halkla İlişkiler Ödülleri" yarıșmasındaki kategorilerden olan kurumsal sosyal sorumluluğu "çevre, eğitim, kültür-sanat, sağlık, turizm, tarım, spor ve diğer" alt kategorilere göre sinıflandırdıkları görülmüştür (Türkiye Halkla İlişkiler Derneği [TÜHİD], 2021). Çalışmada, web sayfalarında içeriklere göre sosyal sorumluluk alanlarının sınıflandırmasının tespit edilmesinde TÜHİ'in değerlendirdiği sosyal sorumluluk kategorilerden yararlanılmıştır.

GSM operatörü markalarının 2020 yılı üçüncü çeyrek itibarıyla toplam 82.8 milyon abone sayısının pazar paylarına göre dağılımına bakıldığında; \%40,7'lik oranla Turkcell'in birinci, \%31.4'lük oranla Vodafone'un ikinci ve \%27,9'luk oranla Türk Telekom'un üçüncü sırada bulunduğu görülmektedir (Bilgi Teknolojileri ve İletişim Kurumu [BTK], 2021). Bu çalışmada, Türkiye'de ürün ve/veya hizmetleriyle faaliyet gösteren Turkcell, Vodafone ve Türk Telekom GSM operatörü markalarının sosyal sorumluluk mesajlarını kurumsal web sayfaları üzerinden değerlendirmek amaçlanmıştır.

82.8 milyon mobil aboneye sahip olan GSM operatörü pazarı ve numara taşımanın kolaylaştığı şartlar düşünüldüğünde, araştırmanın evrenini Türkiye'deki GSM operatörleri, örneklemini ise Turkcell, Vodafone ve Türk Telekom GSM operatörleri oluşturmaktadır. Bu bağlamda bu 3 (üç) GSM markasının sosyal sorumluluğa yönelik mesajları web sayfaları üzerinden içerik analizi yöntemiyle 19.02.2021-05.03.2021 tarihleri arasında incelenmiștir.

Çalışmada sadece Turkcell, Vodafone ve Türk Telekom markaları ele alınmış; Pttcell, BİMcell, taraftar hatları gibi markalar Türk Telekom'un alt yapısını kullandığı için çalışma dışında bırakılmıştır. Bu sebeple çalışma Turkcell, Vodafone ve Türk Telekom markalarıyla sınırlıdır.

Çalışmada, markaların sosyal sorumluluk mesajlarının kurumsal web sayfalarında ne ölçüde yer aldığı, bu bilgilere web sayfalarının neresinde yer verildiği, web sayfalarında sosyal sorumluluğun hangi alanlarıyla ilgili mesajlar sunulduğu ve mesajların hangi iletişim biçimleriyle sunulduğu ve marka değerlerine göre sosyal sorumluluk mesajlarında farklılık olup olmadığıyla ilgili bilgiler verilerek karşılaştırmalı ve bütüncül bir bakış açısı sunulmuştur.

Çalışmada aşağıdaki araştırma sorularına cevap aranacaktır.

Araştırma Sorusu 1: Markalar kurumsal web sayfalarında sosyal sorumluluk çalışmalarıyla ilgili mesajlara yer vermekte midir?

Araştırma Sorusu 2: Markaların kurumsal web sayfalarında sosyal sorumluluk mesajlarına yönelik bilgiler web sayfasının neresinde yer almaktadır?

Araştırma Sorusu 3: Markaların kurumsal web sayfalarındaki sosyal sorumluluk mesajları daha çok hangi sosyal sorumluluk alanıyla ilgilidir? 
Araştırma Sorusu 4: Markaların kurumsal web sayfalarında sosyal sorumluluğa yönelik mesajları hangi iletişim biçimiyle duyurmaktadır?

Araştırma Sorusu 5: Markaların kurumsal web sayfalarında yer alan sosyal sorumluluk mesajları markaların değerine göre farklılaşmakta mıdır?

\section{Bulgular}

Çalışmanın bu bölümünde, yapılan analizler sonucunda GSM operatörü markalarının kurumsal web sayfalarında sosyal sorumluluk mesajlarının görünümüne ilişkin elde edilen bulgulara yer verilmiştir.

\subsection{Web Sayfalarında Sosyal Sorumluluk Mesajlarına Yer Verme Durumu}

Telekomünikasyon sektöründe faaliyet gösteren Turkcell, Vodafone ve Türk Telekom'un kurumsal web sayfalarında sosyal sorumluluk mesajlarına yer verdikleri ve sosyal sorumluluk çalışmalarını paylaştıkları tespit edilmiştir.

Tablo 1. Web Sayfalarında Sosyal Sorumluluk Mesajlarına Yer Verme Durumu

\begin{tabular}{|l|c|}
\hline Markalar & Sosyal Sorumluluk Mesajlarına Yer Verme \\
\hline Turkcell & Var \\
\hline Vodafone & Var \\
\hline Türk Telekom & Var \\
\hline
\end{tabular}

Not: Markalar pazar paylarına göre sıralanmıștır.

\subsection{Sosyal Sorumlulukla İlgili Linklerin Web Sayfalarındaki Konumu}

Markaların sosyal sorumlulukla ilgili mesajlarının web sayfalarının neresinde sunduklarıyla ilgili değerlendirmeye yapıldığında; Turkcell'in, Vodafone'un ve Türk Telekom'un sosyal sorumlulukla ilgili linklerinin başka başlıklar altında yer aldığı görülmüştür.

Tablo 2. Sosyal Sorumlulukla İlgili Linklerin Web Sayfalarındaki Konumu

\begin{tabular}{|c|c|c|c|}
\hline Sosyal Sorumlulukla İlgili Linkler & Turkcell & Vodafone & Türk Telekom \\
\hline Ana sayfada sosyal sorumluluk başlığı altında link & & & $\mathrm{X}$ \\
\hline Alt sayfada sosyal sorumluluk başlığı altında link & & $\mathrm{X}$ & \\
\hline Sosyal sorumluluk başlıklı link yok & $\mathrm{X}$ & & \\
\hline
\end{tabular}

Turkcell sosyal sorumlulukla ilgili mesajlarını alt sayfanın altında bulunan "sponsorluk" linkinin içinde "toplumsal sorumluluk ve sponsorluk" linkiyle; Vodafone alt sayfanın altında bulunan "hakkımızda" başlığının altında "sosyal sorumluluk" linkiyle ve Türk Telekom ise ana sayfada bulunan "hakkımızda" başlığının altında "sosyal sorumluluk" linkiyle mesajlarını paylaştığı tespit edilmiştir.

Burada en dikkat çekici husus, Turkcell'in sosyal sorumlulukla ilgili mesajlarının ana sayfanın altında bulunan "sponsorluk" linkinin içinde "toplumsal sorumluluk ve sponsorluk" linkiyle paylaşmasıdır. Türkiye'de en çok mobil aboneye sahip olan ve pazar payında birinciliği elinde bulunduran Turkcell, sosyal sorumluluk çalıșmalarıyla ilgili mesajlarını halkla ilişkilerin bir başka uygulaması olan sponsorluk başlığı altında paylaşması markanın imajına zarar verebileceği söylenebilir. Turkcell'in geçmişten bu zamana kadar gerçekleștirdiği çeşitli sosyal sorumluluk çalışmaları düşünüldüğünde, mesajlarını sponsorluk linki altında paylaşması kurumsal bir markadan beklenmeyecek yaklaşım olduğu da ifade edilebilir. 


\section{3. İçeriklere Göre Sosyal Sorumluluk Alanları}

Markaların sosyal sorumluluk alanlarına göre çalıșmalarına bakıldığında; Turkcell'in 16 (\%42) mesajla en fazla çevre alanında paylaşım yaptığı, bunu 12 mesajla (\%31) eğitim, 9 (\%24) mesajla toplum ve 1 (\%3) mesajla tarım alanı takip ettiği görülmüștür. Vodafone'un 10 (\%37) paylaşımla toplum, 9 (\%33) paylaşımla eğitim, 6 (\%22) paylaşımla çevre, 1'er (\%4) paylaşımla sağlık ve tarım alanında sosyal sorumluluk mesajlarını ilettiği saptanmıştır. Türk Telekom'un ise en fazla 24 (\%83) mesajla çevre, 3 (\%10) mesajla toplum ve $2(\% 7)$ mesajla eğitim alanında paylaşım yaptığı tespit edilmiştir.

Tablo 3. İçeriklere Göre Sosyal Sorumluluk Alanlarının Web Sayfalarındaki Dağılımı

\begin{tabular}{|l|c|c|c|c|c|c|c|c|}
\hline \multirow{2}{*}{$\begin{array}{l}\text { Sosyal Sorumluluk } \\
\text { Alanları }\end{array}$} & \multicolumn{2}{|c|}{ Turkcell } & \multicolumn{2}{c|}{ Vodafone } & \multicolumn{2}{c|}{ Türk Telekom } & \multicolumn{2}{c|}{ Toplam } \\
\cline { 2 - 9 } & Sayı & Yüzde & Sayı & Yüzde & Sayı & Yüzde & Sayı & Yüzde \\
\hline Çevre & 16 & 42 & 6 & 22 & 24 & 83 & 46 & 49 \\
\hline Eğitim & 12 & 31 & 9 & 33 & 2 & 7 & 23 & 25 \\
\hline Toplum & 9 & 24 & 10 & 37 & 3 & 10 & 22 & 23 \\
\hline Tarım & 1 & 3 & 1 & 4 & - & - & 2 & 2 \\
\hline Sağlık & - & - & 1 & 4 & - & - & 1 & 1 \\
\hline Turizm & - & - & - & - & - & - & - & - \\
\hline Kültür-Sanat & - & - & - & - & - & - & - & - \\
\hline Spor & - & - & - & - & - & - & - & - \\
\hline Toplam & 38 & 100 & 27 & 100 & 29 & 100 & 94 & 100 \\
\hline
\end{tabular}

Markaların konulara göre toplam 94 sosyal sorumluluk paylaşımları incelendiğinde; 46 (\%49) mesajla en fazla çevre alanında, 23 (\%25) mesajla eğitim, 22 (\%23) mesajla toplum, $2(\% 2)$ mesajla tarım ve 1 (\%1) mesajla sağlık alanında paylaşım yaptıkları tespit edilmiştir. Bu verilerden hareketle; GSM operatörü sürdürülebilir bir yaşam için çevre konusuna önem verdikleri görülmekle birlikte, eğitim ve topluma yönelik sosyal sorumluluk faaliyetlerinde de bulundukları anlaşılmaktadır.

Burada ifade edilmesi gereken diğer önemli konu ise, markaların çevreye yönelik sosyal sorumluluk mesajlarını "çevre/doğa" alanında bir link (başlık) üzerinden vermekten ziyade "sürdürülebilirlik" linkiyle paylaştığı görülmüştür. Ayrıca yine markaların kültürsanat, spor ve turizm alanlarında herhangi sosyal sorumluluk mesajı paylaşmadığı, bu alanlarda "sponsorluk" çalışmalarında bulundukları belirlenmiştir.

\subsection{Sosyal Sorumlulukla İlgili Mesajların İletilme Biçimleri}

Markaların web sayfaları sosyal sorumluluk mesajlarını iletme biçimleri açısından kıyaslandığında; Turkcell sosyal sorumlulukla ilgili mesajlarının 19'unda (\%50) metin, 13'ünde (\%34) görsel ve yazılı materyal, 5'inde (\%13) görsel ve işitsel materyal ve 1'inde (\%3) rapor paylaștığı; Vodafone mesajlarının 11'inde (\%41) görsel ve yazılı materyal, 10'unda (\%37) görsel ve işitsel materyal, 4'ünde (\%15) metin ve 2'sinde (\%7) rapor paylaștığı; Türk Telekom ise mesajlarının 20'sinde (\%69) metin, 5'inde (\%17) görsel ve yazılı materyal ve 4'ünde (\%14) görsel ve işitsel materyal paylaştığı tespit edilmiştir. 
Tablo 4. Sosyal Sorumluluk Mesajlarının İletilme Biçimlerinin Web Sayfalarındaki Dağılımı

\begin{tabular}{|l|c|c|c|c|c|c|c|c|}
\hline \multirow{2}{*}{ Mesajların İletilme Biçimleri } & \multicolumn{2}{|c|}{ Turkcell } & \multicolumn{2}{c|}{ Vodafone } & \multicolumn{2}{c|}{ Türk Telekom } & \multicolumn{2}{c|}{ Toplam } \\
\cline { 2 - 10 } & Sayı & Yüzde & Sayı & Yüzde & Sayı & Yüzde & Sayı & Yüzde \\
\hline Metin & 19 & 50 & 4 & 15 & 20 & 69 & 43 & 46 \\
\hline Görsel ve Yazılı Materyal & 13 & 34 & 11 & 41 & 5 & 17 & 29 & 31 \\
\hline Görsel ve İşitsel Materyal & 5 & 13 & 10 & 37 & 4 & 14 & 19 & 20 \\
\hline Rapor/Yıllık Rapor & 1 & 3 & 2 & 7 & - & - & 3 & 3 \\
\hline Basın Bülteni & - & - & - & - & - & - & - & - \\
\hline Kuruluş Yayını & - & - & - & - & - & - & - & - \\
\hline Toplam & 38 & 100 & 27 & 100 & 29 & 100 & 94 & 100 \\
\hline
\end{tabular}

GSM operatör markalarının toplam 94 sosyal sorumluluk mesajını iletme biçimleri değerlendirildiğinde; $43(\% 46)$ mesajla en fazla metin yoluyla paylaşım yapıldığı görülmüş, bunu 29 (\%31) paylaşımla görsel ve yazılı materyal, 19 (\%20) paylaşımla görsel ve işitsel materyal ve 3 (\%3) paylaşımla rapor takip etmiştir. Bu bilgiden hareketle, markalar web sayfalarında sosyal sorumlulukla ilgili paylaşımlarda belli bir düzen içinde mesajlarını hedef kitlelere iletmedikleri ve sadece metin tercih ederek paylaşımlarda bulundukları saptanmıştır. Markaların müşterilere sundukları teknoloji, iletişim teknolojilerindeki gelişme ve hedef kitleler düşünüldügünde mesajların iletilme biçiminde yenilikler yapılması, mesajların web sayfalarında daha düzenli ve sosyal medyanın da aktif, etkin ve web sayfalarına entegre bir şekilde düzenlenmesi gerektiği gözükmektedir.

\subsection{Markaların Değerlerine Göre Sosyal Sorumluluk Çalışmalarına Önem Verme Durumları}

GSM operatörlerinin 2020 yılı marka değerleri ve gerçekleştirdikleri sosyal sorumluluk faaliyetleri kıyaslandığında; 1,361 \$ marka değerlerine sahip olan Turkcell'in gerçekleştirdiği 38 sosyal sorumluluk çalışmasıyla birinci olduğu; 1,087 \$ marka değerine sahip olan Türk Telekom'un gerçekleştirdiği 29 sosyal sorumluluk çalışmasıyla ikinci olduğu ve 19,121 \$ marka değeriyle Vodafone’un ise gerçekleștirdiği 27 sosyal sorumluluk çalışmasıyla üçüncü olduğu görülmektedir.

Tablo 5. Markaların Değerlerine ${ }^{1}$ Göre Sosyal Sorumluluk Çalışmalarına Önem Verme Durumları

\begin{tabular}{|l|l|c|c|}
\hline Marka & Ülke & 2020 Marka Değeri (\$) & Sosyal Sorumluluk Sayıları \\
\hline Turkcell & Türkiye & 1,361 & 38 \\
\hline Vodafone & İngiltere & 19,121 & 27 \\
\hline Türk Telekom & Türkiye & 1,087 & 29 \\
\hline
\end{tabular}

Sosyal sorumluluk çalışmaları marka değerini artırmakta ve markayı olumlu etkilemektedir (Heal, 2005; Aktan \& Börü, 2007; Çelik, 2007). Bu bilgiye ve tablo 5 'teki verilere göre marka değeri ve sosyal sorumluluk açısından ilişki kurmak zor olsa da, Turkcell, Vodafone ve Türk Telekom'un marka değerleri ve gerçekleştirdikleri sosyal sorumluluk çalışmaları kıyaslandığında, global bir marka olan Vodafone'un marka değeri ve gerçekleștirdiği sosyal sorumluluk çalışmalarının, diğer iki markaya göre geride kaldığı görülmektedir. Dolayısıyla Türkiye'nin en değerli markalarından olan Turkcell ve Türk Telekom'un marka değerleri, Vodafone'a yakın olmasa da, sayısal anlamda gerçekleştirdikleri sosyal sorumluluk çalışmalarıyla önemli fark oluşturdukları ifade edilebilir. 


\section{Sonuç ve Değerlendirme}

Ürün ve/veya hizmet sağlayarak kazanan markalar, bunun karşılığında faaliyet gösterdikleri bölgelerdeki toplumun sorunlarına dikkat çekmek, bu sorunların çözümüne yardımcı olmak, toplumla temas etmek ve hayatlara dokunmak amacıyla gönüllük esaslı sosyal sorumluluk çalışmaları gerçekleştirmektedirler. Böylece markalar, sosyal sorumluluk uygulamaları sayesinde hedef kitlelerin algılarında sadece para odaklı yapılar olarak düşünülmelerinin önüne geçilerek, onların kalplerinde ve akıllarında olumlu marka imajı oluşturabileceklerdir.

Sosyal sorumluluk çalışmalarının markalara sağladığı bilinirlik, tercih edilebilirlik ve olumlu marka imajı düşünülerek, Türkiye'de faaliyet gösteren Turkcell, Vodafone ve Türk Telekom GSM operatörü markalarının web sayfaları, sosyal sorumluluk mesajları açısından incelemiş ve araştırmada şu sonuçlara ulașılmıştır:

- Markaların bilgi sağlaması ve hedef kitlelere kendini tanıtması açısından önemli bir iletişim aracı olan web sayfalarında her üç markada sosyal sorumluluk mesajlarını/ çalışmalarını paylaştıkları görülmekle birlikte, sadece Turkcell'in sosyal sorumlulukla ilgili doğrudan ana sayfada veya alt sayfada linki olmadığı tespit edilmiştir. GSM operatörü pazarında (05.03.2021 itibarıyla) \%40.7'lik oranıyla birinci olan Turkcell, sosyal sorumlulukla ilgili mesajlarını alt sayfada halkla ilişkilerin başka bir uygulama alanı olan ve sosyal sorumlulukla yöntemleri bakımından birbirinden farklı olan "sponsorluk" başlığı altında paylaştığı; \%31.4'lük oranıyla ikinci olan Vodafone’un "alt sayfada" sosyal sorumluluk" linkiyle paylaştığı ve \%27.9'luk oranıyla Türk Telekom'un ise "ana sayfada" sosyal sorumluluk linkiyle paylaştığı görülmüştür. Turkcell'in hem sahip olduğu payı hem de bu zamana kadar gerçekleştirdiği sosyal sorumluluk çalışmaları düşünüldüğünde, sosyal sorumluluk mesajlarını "sponsorluk" linki içinde paylaşması önemli bir eksiklik olarak değerlendirilebilir. Ayrıca Vodafone'un web sayfasının altında sayfada "kurumsal sorumluk" ve "sosyal sorumluluk" linkleri bulunmakta, bu iki ayrı linkin de algı karışıklığı oluşturabileceği düşünülmektedir.

- Markalar toplam 94 sosyal sorumluluk mesajı içinde en çok çevre (46; \%49) daha sonra eğitim (23; \%25), toplum (22; \%23), tarım (2; \%2), sağlı (1; \%1) alanlarında paylaşmıştır. Dolayısıyla günümüzün önemli sorunları arasında yer alan küresel ısınma, su kaynakların azalması, hava kirliliği, israf gibi sorunlara engel olmak ve yaşanabilir bir dünya için markaların çözümler ürettiği söylenebilir. Markaların hepsi sosyal sorumluluk alanında en çok çalışma üretilen "çevre" alanına yönelik mesajlarını "sürdürülebilirlik" linkiyle paylaştığı da belirlenmiştir. Yine markaların "turizm, kültürsanat, spor" alanlarında hiçbir sosyal sorumluluk uygulamasında bulunmadığl, bu alanlarda sadece sponsorluk çalışmaları yaptıkları görülmüştür. Dolayısıyla markaların sosyal sorumluluk çalışmalarını temel olarak çevre, eğitim ve toplum alanlarında sınırlandırdıkları belirlenmiştir. Hız odaklı iletişim çağı ve sosyal mecralarla çevrili yaşam düşünüldüğünde, markaların web sayfalarında "dijital sorumluluk" alanlarında gerçekleştirdikleri çalışmaların, sosyal sorumluluk alanında ayrı bir başlık olarak değerlendirilmesine ve güncellenmesine de imkân vereceği söylenebilir.

- Markalar sosyal sorumluluk mesajlarını en çok metin (43; \%46), daha sonra görsel ve yazılı materyal (29; \%31), görsel ve işitsel materyal (19; \%20) olarak paylaştıkları belirlenmiștir. Markaların özellikle çevre alanındaki mesajlarında yoğun olarak metin tercih ettikleri ve nadirde olsa kullandıkları görsellerde geri dönüşüm, yeşil renk, dünya gibi simgeleri kullandıkları görülmüștür. Özellikle teknoloji alanında ürün ve/ veya hizmet saplayan bu markaların sosyal sorumluluk mesajlarını iletirken hem ses, 
görüntü ve metni bir arada sunan platformlarla entegre biçimde paylaşım yapması hem de detaylı bilgi sahibi olmak isteyen kişiler içinde videolarla birlikte yardımcı metin linkleri (Hiper-metin/Hypertext) vermesi gerekmektedir.

- GSM operatörlerinin marka değerleri ve sosyal sorumluluk çalışmaları değerlendirildiğinde, Türkiye'nin en değerli ilk 10 (on) markası arasında bulunan Turkcell (4. sırada) ve Türk Telekom'un (6. sırada) gerçekleştiği sosyal sorumluluk faaliyetleri, Vodafone'u (dünyada 91. sırada) geride bıraktığı tespit edilmiştir. Marka değeri ve sosyal sorumluluk bağlamında Turkcell'in birinci, Türk Telekom'un ikinci ve Vodafone'un üçüncü olduğu belirlenmiş ve Turkcell'in diğer markalara oranla, açık ara sosyal sorumluluk faaliyetlerine verdiği önemde anlaşılmıştır.

Markalar; marka kimliğine uygun, vizyon, misyon ve değerleri ile örtüşen sosyal sorumluluk projeleri üretmeli, bu projeleri sahiplenmeli ve marka iletișimlerini hem kurumsal imajlarına hem de sosyal sorumluluk projelerine zarar vermeyecek şekilde yürütmelidir. Markalar; iletişim dili kullanımlarını, hem sosyal medya kanallarından hem de web siteleri üzerinden aynı titizlikle gerçekleştirmeli, hedef kitle ile açık iletişim yolunu seçmelidirler. Bu bağlamda web siteleri de hedef kitlenin bilgiye ulaştı̆̆ kaynak olduğundan, web sitesi güncellenmeli ve hedef kitlenin kolaylıkla bilgiye erișebileceği şekilde düzenlenmelidir. Web sitesinin kolay kullanımı, kullanıcı dostu olması, bilgiye erişimi hızlandırarak, güncel bir web sitesi üzerinden hedef kitlenin doğru bilgiye hızlı ulaşımını sağlayacaktır.

Hedef kitleler, marka veya markanın sosyal sorumluluk faaliyetleri hakkında bilgi sahibi olmak için 7 gün 24 saat doğrudan kurumun kontrolünde olan web sayfalarına girebilmekte ve bilgiye doğrudan erişmektedirler. Dolayısıyla iletişim teknolojileri alanında öncü olan GSM markaları, kontrol edilebilir iletişim aracı olan kurumsal web sayfalarından sosyal sorumluluk mesajlarını iletirken hedef kitlelerde oluşturacakları algıyı düşünmeli ve herhangi bir olumsuzluğa yol açmadan, iletişim kazaları oluşturup marka imajlarına zarar vermeden doğru bilgi paylaşmaları gerekmektedir.

\section{Notlar}

1 Turkcell ve Türk Telekom için Brand Finance'ın Türkiye'nin en değerli markaları raporu (Brand Finance, 2021); Vodafone için ise dünyanın en değerli markaları raporu dikkate alınarak düzenlenmiştir (Brand Finance , 2021).

\section{Kaynakça}

Abdul Hamid, F. Z., Salleh, S. M., \& Yusof, M. A. (2002). Investor Relations in Developing Countries: A Disclosure Strategy. Şubat 24, 2021 tarihinde https://papers.ssrn. com/sol3/papers.cfm?abstract_id=383040 adresinden alındı

Aksoy, N. (2006). Yerel yönetimlerde halkla ilişkiler ve teknoloji kullanımı. Türk İdare Dergisi (452), 53-62.

Aktan, C. C., \& Börü, D. (2007). Kurumsal sosyal sorumluluk. Kurumsal sosyal sorumluluk: işletmeler ve sosyal sorumluluk (s. 11-36). içinde İstanbul : İgiad Yayınları.

Aktan, C. C., \& Vural, İ. Y. (2007). Çokuluslu şirketler ve kurumsal sosyal sorumluluk. Kurumsal sosyal sorumluluk: işletmeler ve sosyal sorumluluk (s. 139-145). içinde İstanbul: İgiad Yayınları.

Alnıaçık, Ü., Develi, E. İ., Giray, C., \& Alnıaçık, E. (2011). Küresel firmaların yerel sosyal sorumluluk faaliyetleri marka değeri ve marka tercihini nasıl etkilemektedir? Öneri Dergisi , 9 (35), 83-91. 
Anderson, R. H. (1982). Sosyal sorumluluk muhasebesi: ne, nasıl ölçülmeli? (H. Ergin, Dü.) Eskişehir Íktisadi ve Ticari İlimler Akademisi Dergisi , 18 (2), 111-123.

Aydınalp, G. I. (2013). Halkla iliş̧kiler ekseninde kurumsal sosyal sorumluluk. Ankara: Nobel Akademik Yayıncılık.

Bensghir, T. K. (2000). Halkla ilişkilerde etkileşimli iletişim: web (www). Amme İdare Dergisi , 33 (1), 111-131.

Bilgi Teknolojileri ve İletişim Kurumu [BTK]. (2021, Şubat 27). Şubat 27, 2021 tarihinde https://www.btk.gov.tr/uploads/pages/pazar-verileri/uc-aylik-pazar-verileri2020-3-kurumdisi.pdf adresinden alındı

Birden, B. (2016). Çevre etiğinde bireyin ahlaki sorumluluğuna kısa bir bakış. Türkiye Biyoetik Dergisi , 3 (1), 4-14.

Bobbitt, R. (1995). An internet primer for public relations. Public Relations Quarterly , 40 (3), 27-32.

Bowen, H. R. (1953). Social Responsibilities of Businessman. Lowa City: University of Lowa Press.

Brand Finance. (2021, Mart 1). Mart 1, 2021 tarihinde https://brandfinance.com/ wpcontent/uploads/1/brand_finance_global_500_2020_preview.pdf adresinden alındl

Brand Finance. (2021, Mart 1). Mart 1, 2021 tarihinde https://brandirectory.com/ download-report/brand-finance-turkey-100-2020-full-report.pdf adresinden alındl

Carroll, A. B. (2016). Carroll's pyramid of CSR: taking another look. International Journal of Corporate Social Responsibility , 1 (3), 1-8.

Carroll, A. B. (1999). Corporate social responsibility: evolution of a definitional construct. Business and Society, 38 (3).

Carroll, A. B. (1991). The pyramid of corporate social responsibility: toward the moral management of organizational stakeholders. Business Horizons , 34 (4), 39-48.

Ceritoğlu, A. B. (2011). Kurumsal sosyal sorumluluk ve işletmelerin çevre bilinci eksenindeki uygulamalarının tüketici satın alma davranışı ve kurum imajı algısına etkisi. İstanbul: Yalın Yayıncılık.

Certo, S. C. (1997). Modern management. New Jersey: Prentice-Hall International, Inc.

Çakır, S. Y. (2011). Web siteleri ve ikna: teknolojinin ikna gücü. Konya: Tablet Kitabevi.

Çelik, A. (2007). Şirketlerin sosyal sorumlulukları. C. C. Aktan (Dü.) içinde, Kurumsal sosyal sorumluluk: işletmeler ve sosyal sorumluluk (s. 61-84). İstanbul: İgiad Yayınları.

Çöklü, Y. E. (2004). Halkla ilişkilerde medya yönetimi: yeni iletişim teknolojileriyle. İstanbul: Set Systems.

Davis, K. (1960). Can business afford to ignore social responsibilities? . California Management Review , 2 (3), 70-76.

Demirtaş, M. (2015). Türkiye'de yapılan kurumsal sosyal sorumluluk faaliyetlerinin uluslararası girişimler bağlamında değerlendirilmesi. M. Demirtaş (Dü.) içinde, Kurumsal sosyal sorumluluk ve kurumsal itibar (s. 1-54). İstanbul: Derin Yayınları. 
Diken, A., \& Çelebi, M. E. (2015). İşletmelerde iş ahlakı ve sosyal sorumluluk ilişsisi. Değerler bilançosu: felsefe, sosyoloji, kamu, eğitim (s. 213-247). içinde Konya: Çizgi Kitabevi.

Duke, S. (2002). Wired Sciences: use of world wide web and e-mail in science public relations. Public Relations Review , 28 (3), 311-324.

Esrock, S. L., \& Leichty, G. B. (1998). Social responsibility and corporate web pages: selfpresentation or agenda-setting? Public Relations Review , 24 (3), 305-319.

European Commission. (2021, Şubat 20). Şubat 20, 2021 tarihinde Corporate social responsibility \& Responsible business conduct: https://ec.europa.eu/growth/ industry/sustainability/corporate-social-responsibility_en adresinden alındı

Güllülü, U., Ünal, S., Gödekmerdan, L., \& Deniz, A. (2010). Bir kurumsal sosyal sorumluluk projesine karşı tüketici tutumları üzerine araştırma: Turkcell Erzurum çağrı merkezi projesi. Pazarlama ve Pazarlama Araştırma Dergisi , 3 (5), 45-70.

Gürel, T. (2007). Kurumsal sosyal sorumluluk projelerinin iletişimine yönelik profesyonellerin görüşleri ve ödül programlarının kurumsal iletişim sürecinde kullanılması için bir öneri: Türkiye halkla ilişkiler derneği (Tühid) altın pusula halkla ilişkiler ödülleri . İletişim Çalışmaları Dergisi (6), 24-43.

Hatherly, D., Mitchell, R. K., Mitchell, J. R., \& Lee, J. H. (2017). Reimagining profits and stakeholder capital to address tensions among stakeholders. Business \& Society , $00(0), 1-29$.

Hay, R. D., \& Gray, E. R. (1981). Business \& Society: Cases and Text. Ohio: South-Western Publishing Co.

Heal, G. (2005). Corporate social responsibility: an economic and financial framework. The Geneva Papers on Risk and Insurance-Issues and Practice , 30 (3), 387-409.

Higgins, C., Stubbs, W., \& Milne, M. (2018). Is sustainability reporting becoming institutionalised? The role of an issues-based field. Journal of Business Ethics , 147 (2), 309-326.

Hodgetts, R. M., \& Kuratko, D. F. (1991). Management. USA: HBJ, Inc.

Hsieh, H.-F., \& Shannon, S. E. (2005). Three approaches to qualitative content analysis. Qualitative Health Research , 15 (9), 1277-1288.

İlic, D. K. (2015). Kurumsal sosyal sorumluluk ve işletme yönetimi. K. Ören, B. Eser, \& E. Akman içinde, Farklı bakış açılarıyla sosyal sorumluluk (s. 59-96). Ankara: Pelikan Yayıncilık.

Isiri, S. S., \& Crowther, D. (2015). İnsan hakları bağlamında sosyal sorumluluk: ihmal edilen bir prensip. K. Ören, B. Eser, \& E. Akman (Dü) içinde, Farklı bakış açılarıyla sosyal sorumluluk (H. Nalbant, \& M. Kozan, Çev., s. 1-16). Ankara: Pelikan Yayıncılık.

Keith, D. (1973). The case for and against business assumption of social responsibilities. The Academy of Management Journal , 16 (2), 312-322.

Keleş, R., \& Hamamcl, C. (2002). Çevrebilim. Ankara: İmge Kitabevi.

Kent, M. L., \& Taylor, M. (1998). Building dialogic relationships through the world wide web. Public Relations Review , 24 (3), 321-334. 
Kim, I., \& Kuljis, J. (2010). Applying content analysis to web-based content. Journal of Computing and Information Technology, 18 (4), 369-375.

McWilliams, A., \& Siegel, D. (2000). Corporate social responsibility and financial performance: correlation or misspecification? Stratejic Management Journal , 21 (5), 603-609.

Metin, H. (2006). Doktora tezi. Çevre etiğinde bireyin ahlaki sorumluluğuna kısa bir bakış . Konya: Selçuk Üniversitesi Sosyal Bilimler Enstitüsü.

Nalbant, Z. E. (2005). İşletmelerde sosyal sorumluluk ve iş ahlakı. Yönetim ve Ekonomi Dergisi , 12 (1), 193-201.

Neuman, W. L. (2014). Social research methods: qualitative and quantitative approaches. USA: Pearson.

Ölçer, N. (2015). Kurumsal itibar aracı olarak kurumsal sosyal sorumluluk ve bankalar: Garanti Bankası, Akbank ve İş Bankası eğitim projeleri. S. Koçer (Dü.) içinde, Halkla ilişskiler'de uzmanlaşma (s. 25-50). İstanbul: Derin Yayınları.

Peattie, K. (1999). Trappings versus substance in the greening of marketing planning. Journal of Strategic Marketing (7), 131-148.

Peltekoğlu, F. B. (2004). Halkla ilişkiler nedir. İstanbul: Beta Yayınları.

Rasoulzadeh, H., Hosseinipour, S. J., Yusof, N. A., Soltani, M., \& Hashemi, S. (2013). Effect of dimensions of corporate social responsibility on organizationperformance. International Jounal of Innovative Ideas , 13 (2), 37-47.

Seitel, F. P. (2016). Halkla ilişkiler uygulaması. (S. Ç. Mengü, Dü.) Ankara: Nobel Akademik Yayıncilık.

Silsüpür, Ö. (2020). Kurumsal sosyal sorumluluk ve marka imajı. Konya: Palet Yayınları.

Steiner, G. A. (1979). Sosyal denetim raporları. (B. Oba, Dü.) Yönetim Dergisi (11), 37-41.

Timisi, N. (2003). Yeni iletişim teknolojileri ve demokrasi. Ankara: Dost Kitabevi.

Toker, H., \& Tat, M. (2013). Sosyal sorumluluk: kamu ve vakıf üniversiteleri öğrencilerinin sosyal sorumluluğa ilişkin bilgi düzeyleri ve algılarının ölçülmesi. Selçuk İletişim , 8 (1), 34-56.

Top, S. (2015). İşletmelerde yönetim mekanizması anlayıșı bağlamında kurumsal sosyal sorumluluğun yeri. K. Ören, B. Eser, \& E. Akman (Dü) içinde, Farklı bakış açılarıyla sosyal sorumluluk (s. 97-130). Ankara: Pelikan Yayıncllık.

Torlak, Ö. (2013). Kurumsal sosyal sorumluluk alanları. M. C. Öztürk (Dü.) içinde, Kurumsal sosyal sorumluluk (s. 33-48). Eskișehir: Anadolu Üniversitesi Açıköğretim Fakültesi Yayınları.

Tosun, K. (1979). İş hayatının sosyal sorumlulukları. Yönetim Dergisi , 3 (11), 4-11.

Türk Dil Kurumu [TDK]. (2021, Şubat 18). Şubat 18, 2021 tarihinde Türk Dil Kurumu Sözlükleri: https://sozluk.gov.tr/ adresinden alındı

Türkiye Halkla İlişkiler Derneği [TÜHİD]. (2021). Mart 1, 2021 tarihinde http://www. altinpusula.org/19-altin-pusula-yonetmelik.html adresinden alındı 
Warhurst, A., \& Mitchell, P. (2000). Corporate social responsibility and the case of Summitville mine. Resources Policy, 91-102.

Yalın, B. E., \& Silsüpür, Ö. (2017). Kent tanıtımında etkili bir araç olarak web sayfaları: Dokap bölgesi illeri kapsamında bir araștırma. Dokap bölgesi uluslararası turizm sempozyumu bildiriler kitabı (s. 446-452). Trabzon: Karadeniz Teknik Üniversitesi Matbaasi. 


\title{
Social Responsibility Activities of GSM Operator Brands: An Analysis on Corporate Web Pages
}

\author{
Özer Silsüpür (Lect. Ph.D.)
}

\section{Extended Abstract}

Brands operating by undertaking various tasks in the society, are affected by social, economic and technological developments and changes. Essentially, brands are expected to act with the idea of making a profit, but to have the idea of responsibility towards the society is a result of this change. The responsibility which is the acceptance of the consequences of the actions and activities of individuals, has led to the idea that the brands that have gained by providing products and/or services to the society, have responsibilities and duties for the society and this awareness has started to develop on the society (Silsüpür, 2020).

Brands/businesses both consume natural and economic resources without control, pollute the environment/nature depending on their production capacities and activites, cause global warming, as well as the negative effects of economic activities and the decrease in the resources on earth compared to the increasing population have paved the way for the formation of the idea of social responsibility (Top, 2015).

Social responsibility practices have a crucial role in the development of sustainable development, in the formation of social awareness, in completing the lacking actions in the society (Demirtaş, 2015), in changing settled behaviours, improving living conditions, preserving progress, protecting nature/environment, having cultural values, supporting education (Gürel, 2007), creating solutions to problems, perceiving brands posivitively, establishing a bond based on loyalty between customers (consumers) and brands,increasing brand familarity (awareness) and establishing trust in the brand (Silsüpür, 2020).

Web pages; provide the opportunity to share new informations quickly with it's updatable feature, to ensure sharing the information within the corporation and to prevent information pollution, brands informing public about their product and/or services, enabling practices such as sponsorship, social responsibility to be shared with public and strengthen the brand image, thus making it an important reference guide in this era of communication.

It should be emphasized that the information on the web pages is updated and useful, an interesting interface that will make users to visit again, the given links should be up to date and in terms of two-way communication it's important to return the feedbacks (Kent \& Taylor, 1998).

Based on the literature given above, these questions will be answered in this research:

1. Do brands include social responsibility activities on their corporate pages?

2. In which place does the messages regarding social responsbility take part in the brands corporate page?

3. Which social responsibility field is more about the social responsibility messages on the brands corporate web page? 
4. In which way of communication does the brands use to announce messages about social responsibility on their corporate page?

5. Do the social responsibility messages on the corporate web pages of the brands differ according to the value of the brands?

In this study, Esrock and Leichty's (1998) study regarding the appearance of social responsibility messages on the web pages was updated and used while taking social responsibility literature into consideration.

Brands operating a product and/or a service, Turkcell, Vodafone and Turk Telekom GSM operators' social responsibility messages assessed through corporate web pages. In this respect, corporate web pages were examined with content analysis method between 19.02.2021-05.03.2021.

Taking into the consideration the recognition that social responsibility activities have provided to brands, preferability and positive brand image, Turkcell operating in Turkey, Vodafone and Turk Telekom GSM operator brands web pages were examined in terms of social responsibility messages and has reached the following results :

- It is seen that web pages, which is important way of communication in terms of brands' providing information and introduce themselves to the target audiences, these three brands have shared social responsibility messages/activities, it has been determined that only Turkcell does not have a direct link on social responsibility on the homepage or sub-page. Ranking first in the GSM operator market with 40.7\%, Turkcell shared its messages about social responsibility under the heading of "sponsorship" which is another application area of public relations and different in terms of social responsibility and methods; It was observed that Vodafone, which ranked second with a rate of $31.4 \%$, shared with the "social responsibility" link on the "bottom page" and Turk Telekom shared it with the social responsibility link "on the home page" with a rate of $27.9 \%$.

- Brands have shared the most about environment (46; \%49) among the total 94 social responsibility messages, then education (23; \%25), society (22; \%23), agriculture (2; $\% 2$ ), health (1; \%1). Therefore, it can be said that brands prevent and create solutions for problems such as global warming which is one of the most important issues of present-day, reduction in the water resources, air pollution, wastage for a more liveable world. It has also been determined that all brands share their messages regarding the field of "environment", where the most work has been produced in the field of social responsibility, via the "sustainability" link. It has also been observed that, brands do not implement any social responsibility practices in the fields of "tourism, culture-arts, sports", and they only do sponsorship activities in these areas.

- Brands shared their social responsibility messages mostly as text $(43 ; 46 \%)$, then visual and written material (29; 31\%), visual and audio material $(19 ; 20 \%)$. It has been observed that brands prefer text heavily, especially in their environmental messages, and rarely use symbols such as recycling, green color, and the world in the images they use.

- The GSM operators' brand values and social responsibility efforts have been assessed, Turkcell (ranked 4) is among the Turkey's most valuable first 10 (ten) brands and Turk Telekom (ranked 6) with its social responsibility activities, both surpassing Vodafone 
(ranked 91 in the world). In the context of brand value and social responsibility, it has been determined that Turkcell is the first, Turk Telekom is the second and Vodafone is the third, and it is understood that Turkcell gives importance to social responsibility activities by far compared to other brands.

Keywords: Social Responsibility, Corporate Web Pages, GSM Operator Brands, Content Analysis.

Bu makale intihal tespit yazııımlarıyla taranmıştır. Intihal tespit edilmemiştir.

This article has been scanned by plagiarism detection softwares. No plagiarism detected.

Bu çalışmada "Yükseköğretim Kurumları Bilimsel Araştırma ve Yayın Etiği Yönergesi” kapsamında uyulması belirtilen kurallara uyulmuştur.

In this study, the rules stated in the "Higher Education Institutions Scientific Research and Publication Ethics Directive" were followed.

Araştırma tek bir yazar tarafından yürütülmüştür.

The research was conducted by a single author.

Çalışma kapsamında herhangi bir kurum veya kişi ile çıkar çatışması bulunmamaktadır.

There is no conflict of interest with any institution or person within the scope of the study. 